\title{
Mechanical Dolls and Rank Ladies
}

\author{
Linda Mizejewski, Ziegfield Girl: Image and Icon in Culture and Cinema \\ (Durham: Duke University Press, 1999);
}

M. Alison Kibler, Rank Ladies: Gender and Cultural Hierarchy in American
Vaudeville (Chapel Hill: University of North Carolina Press, 1999).

Florenz Ziegfeld began his rise in showbiz by promoting the strongman the Great Sandow at the 1893 Colombian Exposition in Chicago - as part of the draw, Ziegfeld encouraged proper female audience members to come and touch Sandow's remarkable physique. Earlier in his Barnumesque apprenticeship, Ziegfeld, the son of a classical musician, supposedly captivated an audience with his ballyhoo for "Brazilian Invisible Fish" - an empty bowl of water about which he eloquently rhapsodized. Eventually Ziegfeld gave up on strongmen and invisible products to push a seemingly-genuine commodity: the All-American Girl, sexy, wholesome, heterosexual, willowy, and white. In Ziegfeld Girl: Image and Icon in Culture and Cinema, Linda Mizejewski examines the discourse surrounding the Follies, relying on the contemporary filters of race, class, ethnicity, and gender. She successfully places the Follies in the context of the burgeoning consumer culture of the early twentieth century. Somewhat less successfully, Mizejewski argues that shifts in the Follies' imagery mirrored shifting standards of beauty related to nationalism and the racial threat of competing African-American musical comedies and Broadway showcases.

To Mizejewski's credit, her task is a difficult one. Robert C. Allen, in Horrible Prettiness (1991), a history of burlesque in the nineteenth century, placed the Ziegfeld Girl, the packaged commodity, as the endpoint to the rowdy history of women in burlesque and as proof of the eventual containment of women in theatre. But Allen's narrative line was a little too neat. Mizejewski argues that even within the highly formalized confines of the Follies, the show's narratives and iconography revealed the strains and stresses, onstage and off, that the packaging attempted to hide. Those stresses included increasing social freedom, an accompanying gender-role anxiety, and conflicts stemming from America's far from homogenous racial and ethnic population. These stresses and strains also dictated the refashioning of the Follies through the years.

The Zeigfeld Girl began as an upscale version of the chorus girl. The chorus girl rose to prominence at about the same time as the department store, as Americans took to the merchandising of all types of commodities. After making that point, Mizejewski traces the history of the "cult of the chorus girl." Popular theatre in the 1890 s, influenced by the Parisian music halls, began to develop chorus numbers which required long lines of female dancers 
wearing tights and showing off their legs as they danced in mechanical patterns. Mizejewski argues that the "cult of the chorus girl" had some kinship with the rise of the New Woman. The chorus girl was a liberated woman of working class origins who might be read as a good girl, a zesty nonconformist, or as a scheming vamp. She was liberated, unpredictable, and featured in many forgettable novels. Mizcjewski recounts the rags to riches plot of some of these novels, but ignores the most famous depiction of a chorus girl in literature, Dreiser's Sister Carrie. Mizejewski points out that such models of liberated women posed a threat. The middle class version of the New Woman, the Gibson Girl, with her athleticism had lesbian connotations that Ziegfeld largely was able to erase in his showgirl.

The first Ziegfeld Girl, Anna Held, began in Yiddish theatre in Europe and had already repackaged herself as a "French" chanteuse when Ziegfeld discovered her and began to manage her career and highlight her in his early revues. At elaborate press events in New York, Held spoke naughtily of the pleasures of marriage, dressed extravagantly, gave tips on fashion and beauty, and took her famous bath in a tub of milk. Held, as a beauty, had to claim another, "whiter" ethnicity and deny her Jewish ancestry. This at the same time that comediennes like Fanny Brice, serving as comic foils in the Follies, needn't hide their Jewish roots. (Mizejewski doesn't mention that Brice was the recipient of a much-publicized "nose bob" in the 1920s). Mizejewski argues that Held's mischievous and ribald presence as well as her dark looks and short voluptuous figure eventually were seen as too foreign, too European, and too Jewish. Ziegfeld, already mistaken for Jewish in the public eye, needed to whiten his act. The impresario's next prototype for the Ziegfeld Girl, Billie Burke (later the Good Witch in the Wizard of $O z$ ) was blonde, tall, and willowy. Billie was the wholesome girl next door, an anglicized beauty. Mizejewski makes Ziegfeld's change in starlet-wives in 1914 bear a heavy historical load. In her account, this decision seems to all but inaugurate the fad for eugenics and the fears of race suicide that had long been a part of racial discourse.

What was the Follies' formula? By the 1920s, the mechanics were thoroughly codified. Production numbers juxtaposed the "B Team," the chorus girls, or smaller dancers, aka "ponies" against the "A Team," the tall, slow paraders, or showgirls (often recruited from high fashion showrooms). The "A Team" primarily were the bizarrely fetishized woman turned into windmills, gold coins, and battleships that populated choreographer Busby Berkeley's stage and film sequences.

Woven between these two prototypes of the Ziegfeld Girl were the comic foils, whether the feisty Jewish comedienne Fanny Brice, the cross-dressing female impersonator Julian Eltinge, or the black comedian and singer Bert Williams. Mizejewski debates whether these foils contested the Follies' privileging of white Anglo-Saxon heterosexuality, or merely made a more convincing case for the audience to examine then reject such deviance. 
Mizejewski raises the same issue when describing the frequent blackface more precisely "cafe au lait" - performances of Ziegfeld Girls. They crossed a boundary but in so doing only reinforced that boundary. For example, though they could impersonate high yellow girls onstage, Ziegfeld Girls were not allowed to get suntans. But in one 1922 number they could sing "It's Getting Dark on Old Broadway." Likewise, the popular African-American comedian Bert Williams never appeared on stage with the showgirls.

Ziegfeld Girl is an intelligent and game work, but the limitations Mizejewski establishes early on - her determination to examine the Ziegfeld Girl as icon, and not as an individual trying to flourish within a new sort of gilded cage - makes this book at times arid and repetitive. Mizejewski's final chapter reveals just how many Ziegfeld-related films there are - and draws into question whether they are worthy of her micro-examination. The book's best chapter is the first, which centers on Anna Held - here Mizejewski's interpretations are based on ample source materials. Mizejewski insists, no doubt correctly, that the reader can turn to other sources to read the memoirs of Ziegfeld Girls, yet less emphasis on "representation" and more snippets from their lives would not only have enlivened this narrative, but also would have helped show how images of "glorified" American femininity enforced "the impossible demands of bourgeois white femininity."

In Rank Ladies: Gender and Cultural Hierarchy in American Vaudeville, Alison Kibler highlights the vaudeville acts of various rowdy "rank ladies," such as white minstrels, acrobats, ethnic comediennes, and cross-dressing female Shakespeareans. Kibler argues that like these rank ladies on stage, vaudeville audiences also sometimes didn't "know their place." Kibler looks at the battles vaudeville management launched to create what other historians have described as the standardized audience. Working men, African Americans, immigrants, and white middle class families all often mingled in the same vaudeville house, though usually stratified according to orchestra, balcony, and gallery sections. Well aware of this diversity, vaudeville circuit bookers attempted to cater to all tastes, varying the ten acts of a typical bill to include spectacles, comedy, and such highbrow acts as snippets of Shakespeare's plays, or renditions of opera or classical music. Yet tensions inevitably resulted from this democratic milieu, in which "high" culture was unraveled and "low" culture uplifted. Kibler looks at the "battles" vaudeville management launched to control audiences and union-prone performers; she also shows how women figured in these skirmishes.

Kibler does an excellent job of charting audience dynamics by looking at the record books vaudeville theater managers kept, and the letters they sent each other to appraise performers. These letters describe the audience's reactions - whether they found acts too high-falutin', too crass, or too dull, and whether or not the audience was prompted to break the rules of decorum and return to nineteenth century boisterousness. The managers' notes Kibler 


\section{Left History 7.1}

consulted make it clear that the vaudeville audience wasn't as easily tamed as historians sometimes have implied. Kibler shows that the rhetoric of uplift, meant to play to middle class women, could sometimes draw blanks. In shocked tones, managers describe women's delighted response to barely-clad male acrobats and their pleasure at gazing at strongmen like the Great Sandow, and their inappropriate enjoyment of recreations of "savage" boxing matches. The managers found it easier when they could deal with controversy with such notes as "ladies offended" and "the boys approved." The managers' letters also show that African-Americans, never the rowdy force feared, were either forbidden entrance to theaters, or seated in segregated sections of the theater. However, when top-notch African-American performers came to town, the managers whined about the horrors of selling orchestra seats "to coons."

After addressing the "audience question," Kibler moves on to outline the acts and careers of various female performers. Her chapter "Corking Girls" shows how the minstrel tradition blended into the sexual spectacles Ziegfeld perfected. Many white female chorus girls with song and dance talent discovered that they could improve their earnings by leading "pickaninny acts." "Blacked up," these women could leave respectability behind, wiggle and shimmy and act out the part of a wild woman, while dancing on stage with a chorus of African American children and youths. Many of these women tended to be comically big-bodied, and fell into a minstrel stereotype pushed at the turn of the century, that of the Mammy. Kibler argues that in this urban, industrial setting, the "mammy" fed pastoral dreams of old plantation life. Sophia Tucker - who eventually succeeded without performing in blackface and May Irwin were two prime examples of "mammies," clownish, goodhumored performers, whose station in life, as head of the household and kitchen, also showed allegiance to the bourgeois ideal of "true womanhood."

"Corking Girls" also became direct antecedents to Ziegfeld Girls through the work of Ned Wayburn, a minstrel performer and producer who later directed dance sequences for Ziegfeld. Wayburn experimented with productions of chorus girls in blackface, such as the "Minstrel Misses," which combined sexual spectacle with minstrelsy. In these productions, Wayburn showed the penchant for standardization that Ziegfeld shared. He chose chorus girls without formal training in dance and song and molded them to "work together in unison." Like Ziegfeld, Wayburn had exacting standards. He placed a woman's physical measurements over beauty, prizing "regularity" and insisting that "the calf, ankle, waist-line and neck measurements must be right."

The book's most fascinating chapters outlines the career of Ruth Budd, "The Upside Down Lady" who broke into vaudeville from the lowbrow forum of circuses. The press often referred to Budd as the "suffragist of the steel biceps." She began in her teens, performing with her younger brother Giles. Their trapeze act was unusual because the quite pretty and somewhat 
voluptuous Ruth Budd took on the masculine role in their act, swinging her brother around below her while she dangled from the trapeze. Kibler notes that such against the grain gender stances were not all that unusual for acrobats as slender boy trapeze artists often dressed up as girls to wow audiences with their physical abilities. But this was often because men didn't like working with women - and were not willing to place their trust in a woman's physical abilities.

When her brother Giles dropped out after a leg injury, Budd managed to improve her billing by camouflaging her act as song and dance, and dubbing herself, "The Girl With the Smile." Budd's new act began with her powdering herself at a makeup table while singing. Her maid then helped her out of her dress and Budd hid behind the curtain, revealing a naked arm and shoulders. She smiled flirtatiously at the audience, saying, "Soon you'll see more of me." Another curtain then opened to reveal her trapeze apparatus and she appeared in her skin-tight white union suit to began her acrobatics.

Various career decisions enhanced Budd's notoriety. The first, when she took on the female Tarzan role of "Darwa" in the 1919 silent film $A$ Scream in the Night. In the film, Budd's character Darwa is the subject of a somewhat vague experiment in evolution. A scientist abandons her to the Amazon jungles as a child, and even locks her up in a cage with a gorilla to experiment in "cross species" mating. Her athletic ability helps her escape. Eventually she returns to society and is engaged to a gentlemen, but finds herself haunted by her (literally) "wild" past. The movie was purportedly a critique of Darwin - by denying Darwa's ultimate resemblance to an ape. Kibler suggests the film also played to the nineteenth century view of women as "arrested males." This theory defined women as more primitive and animalistic versions of men, prone to hysteria and raging passions if not contained.

Budd's film role as the female Tarzan, and her one-year engagement to Karyl Norman, a female impersonator who called himself "The Creole Fashion Plate" led to public speculation about her ultimate femininity. Some print accounts discussed her preference for wearing men's suits when offstage. Budd, like the athletic and energetic New Woman of the time was tarnished with the image of the deviant. Her vaudeville career continued through the $1920 \mathrm{~s}$. She then married a stagehand, appeared occasionally in circuses, and helped her husband run a grocery in Fort Wayne, Indiana.

After exploring vaudeville's audiences, and profiling women performers who refused to act like "ladies," Kibler closes the book with an account of labour struggles within vaudeville. She traces out the unsuccessful efforts of the vaudevillians' labour organization, the White Rats of America, to buck vaudeville magnate Benjamin Keith and his righthand man, Edward F. Albee. Part of the White Rats' failure as a union was a result of their definition of themselves as labourers first, and artists second. Because of this (or hierarchical antipathy), the stage actors who often did short runs in vaudeville 
refused to ally with them.

The White Rats ran two major strikes. In the first, in 1901, they gained concessions from the Vaudeville Management Protective Agency (VMPA). For a while, the United Booking Agency that Keith ran stopped deducting commissions from the performers paychecks, but this practice was soon reinstated. When the VMPA crushed the White Rats' 1916-17 strike, management forced performers to join their own house-run union, the National Vaudeville Association, and blacklisted those who refused, relegating them to the second-tier vaudeville houses.

Kibler points out that though the White Rats at first refused women admittance, they later relied on tales of women's sexual victimization at the hands of management to try to rally support. The White Rats' narrative of female victimization was undercut by the fact that the women who joined their auxiliary were often at the forefront of picketing efforts. In 1920, the White Rats argued an anti-trust suit against Keith before the Federal Trade Commission. The White Rats claimed that Keith, who owned numerous theaters and controlled the booking in others, had the power to blacklist performers, lower wages, require deductions of booking commissions from paychecks, increase the number of performances daily and otherwise control the industry. They also argued that despite management's claim of creating a respectable form of theater, female performers often were sexually molested by managers and bookers, or cast adrift in the midst of a tour, making them quite vulnerable to sexual predators. In response, Keith had many actresses testify and voice concerns about the White Rats' goals, claiming if the union succeeded in creating a "closed shop" actresses from the legitimate stage would be edged out of vaudeville, and vaudeville would suffer from lack of exposure to high-brow art forms.

Kibler concludes with a discussion of the quick fade out of vaudeville shortly after management's triumph over the White Rats. She shows how many of the accounts of vaudeville's end neatly configure with the modernist rejection of Victorian values, and the mass culture critics' analysis of the new mass audience's passive, feminine character. Keith and Albee would argue that they turned a once raunchy, "low" masculine entertainment form into a respectable and decent venue. Many commentators, like the White Rats, however, argued that the early energy and boisterousness of vaudeville was diluted when male performers were edged out by girl revues like those of Wayburn and Ziegfeld. They also argued that the homogenization of acts was a result of Keith's catering to a wholesome "feminine" audience. While Kibler doesn't reject these narratives of standardization, she adds to the dialogue with her evidence of the many female performers, who in this same era, were offering rowdy, energetic, and "rank" acts on vaudeville stages.

Ziegfeld Girl and Rank Ladies complement each other well. Both examine the development of standardized entertainment forms and the uses of "sexual 
spectacle" to that end. Mizejewski's micro-analysis is insightful; Kibler's study, however, offers a more gripping account of female performers in the early twentieth century. Her rendering is more sure-footed historically when she explores the intersection of high and low culture and discusses that era's gender and racial discourses. Kibler's examination of the vaudeville audiences is unique, and her material vividly reveals how female performers, both on stage and off, contested the status quo of power relations.

Fred Nadis

University of Texas

\section{Democracy and the Colonial Heritage in Africa: Revisiting Mamdani's Citizen and Subject}

Mahmood Mamdani's Citizen and Subject has become one of the most talkedabout contributions to African studies in recent years. The review article which follows represents a commentary on Mamdani. It amplifies substantially a short review which has been published previously in the African Sociological Review. That review ventured to make a number of critical comments on the book which dispute some of its emphases while elaborating on its themes. This article will attempt to develop these points somewhat further. The idea, however, is not to take away from the value and significance of Mamdani's book which represents an important and original contribution.

Others have in fact disputed its originality. As history, Mamdani's concentration on "decentralised despotism," in effect the indirect rule systems that were in force during much of the colonial period, is of course not original. There are accounts still worth reading that understood this system well, perhaps the more so for being close to the colonial period in time, such as Thomas Hodgkin's Nationalism in Colonial Africa, Michael Crowder's West Africa under Colonial Rule or William Derman's Serfs, Peasants and Socialists. It has long been known that the French, who were rather uninterested in questions of legitimacy, would occasionally turn a favoured cook into a chef du canton just as they later turned Bokassa into a president and emperor. Even for South Africa, a number of writers have looked at the subject, with David Welsh's study of the Shepstone system in Natal a particularly important pioneering volume. Norman Etherington is one historian who long ago recognised Natal specifically as an influence on the colonial state emanating out to the rest of (at least) British Africa.

But Mamdani, as he has had to point out repeatedly, is not really trying to compete with the historians. He is instead doing what they do so rarely, apply their wisdom effectively and systematically to contemporary problems. In this case, his work is really directed towards the 1990s debate on democratisation 